\title{
Response of Some Egyptian Cotton Cultivars to Foliar Spray by Some Microelements
}

\author{
El-Saeed M. M. El-Gedwy*; Abo-Baker E. M. Gadallh** and Rania M. Abdel-Twab ${ }^{* *}$ \\ * Faculty of Agriculture - Benha University. \\ ** Cotton Research Institute - Agricultural Research Center - Giza - Egypt. \\ Corresponding author: alsaeed.algedwy@fagr.bu.edu.eg
}

\begin{abstract}
Two field experiments were conducted on the Farm of Agricultural Research and Experiment Center, Faculty of Agriculture Moshtohor, Benha University, Toukh Directorate, Kalubia Governorate, Egypt, during the two successive seasons of 2015 and 2016 to study the effect of foliar spray by eight micronutrient treatments, i.e. without application (control), $\mathrm{Zn}, \mathrm{Mn}, \mathrm{Fe}, \mathrm{Zn}+\mathrm{Mn}, \mathrm{Zn}+\mathrm{Fe}, \mathrm{Mn}+\mathrm{Fe}$ and $\mathrm{Zn}+\mathrm{Mn}+\mathrm{Fe}$ on growth, yield components and yield as well as fiber quality properties for the two Egyptian cotton (Gossypium barbadense, L.) verities, i.e. Giza 86 and Giza 88 . The experimental design was split plot design in four replications.

The obvious results of this investigation can be summarized as follows:

Significant differences were detected for all growth, yield components and yield as well as fiber properties of cotton among the two Egyptian cotton cultivars during 2015 and 2016 seasons. Giza 86 cultivar significantly surpassed Giza 88 cultivar and gave the greatest mean values of plant height, No. of sympodial branches/plant, No. of open bolls/plant, seed cotton yield/plant, boll weight, lint $\%$, lint cotton yield/plant, seed index, seed cotton yield/fed, lint cotton yield/fed, fiber elongation $\%$, micronaire value, fiber maturity ratio and fiber reflectance in the both seasons. While, Giza 88 recorded the highest mean values of upper half mean length, length uniformity index, fiber strength and fiber yellowness degree in the two seasons. Data revealed that the differences between the studied eight microelements treatments on growth, yield components and yield as well as fiber properties of cotton during 2015 and 2016 seasons were significant except, fiber reflectance and fiber yellowness degree were not significant. The application of combined of $\mathrm{Zn}+\mathrm{Mn}+\mathrm{Fe}$ treatment gave significantly the greatest mean values of plant height, No. of sympodial branches/plant, No. of open bolls/plant, seed cotton yield/plant, boll weight, lint \%, lint cotton yield/plant, seed index, seed cotton yield/fed, lint cotton yield/fed, upper half mean length, length uniformity index, fiber strength, fiber elongation $\%$, micronaire value and fiber maturity ratio in the both seasons. Planting Giza 86 which foliar spray by mixed $\mathrm{Zn}+\mathrm{Mn}+\mathrm{Fe}$ treatment significantly recorded the highest mean values of No. of open bolls/plant, seed cotton yield/plant, boll weight, lint cotton yield/plant, seed cotton yield/fed, lint cotton yield/fed and fiber maturity ratio in the first and second seasons. Meanwhile, planting Giza 88 under the same micronutrients application surpassed the other combinations in upper half mean length, length uniformity index and fiber strength during the both seasons.
\end{abstract}

Key words: Egyptian cotton, cultivars, micronutrients, Zinc, manganese, iron, fiber properties

\section{Introduction}

Cotton is considered the main fiber crop in Egypt as well as the world. Egyptian statistics indicates decreasing of cotton cultivated area from 851283 fed on 1991 year to about 216554 fed on 2017 year, with decreasing percent of about $74.56 \%$ that lead to a decrease in cotton production from 5826000 kentars on 1991 year to about 1357000 kentars on 2017 year, with decreasing percent by about $76.71 \%$ in 2017 year comparing with the year 1991 (Egyptian Cotton Gazette, 2017). One of the lowest cotton cultivated area, due to unfair prices to producers and better net profits from alternatives crops especially grains, in the same time costs of cotton inputs. In addition, the very high cost of hand picking and insufficient trained picking workers. The decrease of cotton production in recent years has a negative reflection on local and international market supply. Therefore, a great effort should be continued to improve its quality and quantity either through cultural practices and breeding programs. The cotton yield or any other economic character, is influenced by the various agronomic practices especially the amount of fertilizers or plant density. Therefore, the important question is, what is the most suitable amount of nitrogen fertilizer, how many plants per fed are needed with suitable distribution for these plants in the field to obtain the maximum yield with high quality. The cultivated area of cotton is going lower year after year, in spite of its importance for national economy, textile industry, food oil and animal feed production and also its role in increasing and maintenance of soil fertility.

Several investigators showed that cotton cultivars differed in growth, yield and its components, i.e. plant height, No. of sympodial branches/plant, No. of open bolls/plant, seed cotton yield/plant, boll weight, lint $\%$, lint cotton yield/plant, seed index, seed cotton yield/fed and lint cotton yield/fed (El-Kashlan $\boldsymbol{e t}$ al., 1995; Nichols et al., 2004; Sawan et al., 2006; Elayan, 2008; Ali et al., 2009; Saleem et al., 2010; Ali and Hameed 2011; Ayissa and Kebede 2011; Baraich et al., 2012; Abdallah and Hanaa, 2013; 
Aslam et al., 2013; Jahedi et al., 2013; Eleyan et al., 2014; Eleyan et al., 2015 and Mahdy et al., 2017). There are also differences between cotton cultivars on measurements of fiber properties, i.e. upper half mean length, length uniformity index, fiber strength $(\mathrm{g} / \mathrm{tex})$, fiber elongation $\%$, micronaire value, fiber maturity ratio, fiber reflectance ( $\mathrm{Rd} \%$ ) and fiber yellowness degree $\left({ }^{+} b\right)$ as described by ElKashlan et al., 1995; Nichols et al., 2004; Sawan et al., 2006; El-Sayed and Sanad 2007; Gururajan 2007; Elayan, 2008; Saleem et al., 2010; Alitabar et al., 2012; Abdallah and Hanaa, 2013; El Messiry and Abd-Ellatif 2013; Ibrahim, 2013; Jahedi et al., 2013; Eleyan et al., 2014 and Eleyan et al., 2015.

Foliar application of micronutrients plays an important role in changing growth and physiological characteristics of cotton. In optimizing fertilization strategies, inclusion of foliar application improves fertilizer use efficiency and reduces environmental pollution. Foliar application of micronutrient mixtures during flower and boll development stages have been shown to be effective in efficient utilization of nutrients by cotton and thereby reduce boll shedding and increase the yield. Apart from major nutrients, micronutrients also play an important role in seed production. The dire need for intensive land use drew attention for applying micronutrients to cotton. Essential micronutrients like zinc, iron and manganese play an important role in physiology of cotton crop and these are being a part of enzyme system or catalyst in enzymatic reactions. They are required for plant activities such as aspiration, meristamatic development, chlorophyll formation, photosynthesis, energy system, protein and oil synthesis, gossypol, tannin and phenolic compounds development. Certain micronutrients may help to secure uniform emergence, rapid seedling growth and healthy plant stand. Some beneficial effects on seed yield and quality as reflected in viability may be achieved by applying micronutrients. Effects of foliar application of micronutrients on cotton yield and fiber quality have been widely studied. Generally, the plant requires a wide cultivar of elements to improve the growth, yield and fiber quality. El-Kashlan et al., 1995; Soomro et al., 2000; Rezaei and Malakouti, 2001; Mamatha 2007; Sawan et al., 2007; Elayan, 2008; Sawan et al., 2008; Ali et al., 2011; Abdallah and Hanaa, 2013; Radhika et al., 2013; Yaseen et al., 2013; Eleyan et al., 2014; Khalid et al., 2015; Singh et al., 2015 and Emara, 2016 showed that foliar application by micronutrients increased cotton growth, yield and its components, i.e. plant height, No. of sympodial branches/plant, No. of open bolls/plant, seed cotton yield/plant, boll weight, lint $\%$, lint cotton yield/plant, seed index, seed cotton yield/fed and lint cotton yield/fed. El-Kashlan et al., 1995; Sawan et al., 2007; Elayan, 2008; Sawan et al., 2008; Abdallah and Hanaa, 2013; Radhika et al., 2013; Yaseen et al., 2013; Eleyan et al., 2014 and Emara, 2016 indicated that fiber properties, i.e. upper half mean length, length uniformity index, fiber strength $(\mathrm{g} / \mathrm{tex})$, fiber elongation $\%$, micronaire value, fiber maturity ratio, fiber reflectance $(\mathrm{Rd} \%)$ and fiber yellowness degree $\left({ }^{+} b\right)$ were significantly improved with foliar application of micronutrients.

The significant interaction between Egyptian cotton cultivars and micronutrients application treatments was shown on some cotton growth, yield components and yield as well as fiber quality properties as described by El-Kashlan et al., 1995; Elayan, 2008; Abdallah and Hanaa, 2013 and Eleyan et al., 2014.

The aim of this study was to determine the effect of foliar application zinc, manganese and iron on growth characters, yield, yield components and fiber properties of some Egyptian cotton cultivars, i.e. Giza 86 and Giza 88.

\section{Materials and Methods}

Two field experiments were carried out at the Farm of Faculty of Agriculture at Moshtohor, Benha University (Toukh Directorate, Kalubia Governorate, Egypt), during the two growing seasons 2015 and 2016. The aim of this study was to investigate the effect of some microelements, i.e. zinc, manganese and iron on growth, yield components, yield and fiber properties for the two Egyptian cotton cultivars. Soil texture of the experimental site was clay of $\mathrm{pH}$ nearly of 8.00 . The physical and chemical properties of the experimental soil were determined according to standard methods outlined by Jackson (1973). Available manganese and iron were determined using Atomic Absorption Spectrophotometer (AAS) after extracting the soil with DTPA as proposed by Lindsay and Norvell (1978) and represented in Table 1 in each of the two growing seasons.

Every experiment included 16 treatments which were combination of the two Egyptian cotton cultivars and eight microelements foliar spray, the levels of these factors were as follows:

\section{A- Two Egyptian cotton cultivars:}

1- Giza 86 cultivar as long staple cultivar, characterized by high yield and extra fineness of fiber (cultivated).

2- Giza 88 cultivar as extra-long staple cultivar, (cultivated).

B - Eight microelements treatments:

1- Control (without microelements application).

2- $\mathrm{Zn} \mathrm{So}_{4} 0.4 \%$ (Zn).

3- $\mathrm{Mn} \mathrm{So}_{4} 0.4 \%$ (Mn).

4- $\mathrm{Fe} \mathrm{So}_{4} 0.4 \%(\mathrm{Fe})$.

5- $\mathrm{Zn} \mathrm{So}_{4} 0.4 \%+\mathrm{Mn} \mathrm{So}_{4} 0.4 \%(\mathrm{Zn}+\mathrm{Mn})$.

6- $\mathrm{Zn} \mathrm{So}_{4} 0.4 \%+\mathrm{Fe} \mathrm{So}_{4} 0.4 \%(\mathrm{Zn}+\mathrm{Fe})$.

7- $\mathrm{Mn} \mathrm{So}_{4} 0.4 \%+\mathrm{Fe} \mathrm{So}_{4} 0.4 \%(\mathrm{Mn}+\mathrm{Fe})$.

8- $\mathrm{Zn} \mathrm{So}_{4} 0.4 \%+\mathrm{Mn} \mathrm{So}_{4} 0.4 \%+\mathrm{Fe} \mathrm{So}_{4} 0.4 \%$ $(\mathrm{Zn}+\mathrm{Mn}+\mathrm{Fe})$. 
Table 1: Physical and chemical properties of the experimental soil units of the two growing seasons (2015 and 2016).

\begin{tabular}{|c|c|c|}
\hline \multirow{2}{*}{ Properties } & \multicolumn{2}{|c|}{ Season } \\
\hline & 2015 & 2016 \\
\hline \multicolumn{3}{|l|}{ Chemical analysis } \\
\hline E.C. & 2.13 & 2.25 \\
\hline $\mathrm{pH}(1: 2.5)$ & 7.83 & 7.91 \\
\hline $\mathrm{CaCO}_{3} \%$ & 2.91 & 2.96 \\
\hline O.M \% & 2.52 & 2.44 \\
\hline $\mathrm{N} \%($ total $)$ & 0.223 & 0.209 \\
\hline $\mathrm{N}(\mathrm{ppm})$ (available) & 70.31 & 73.15 \\
\hline $\mathrm{P} \%($ total $)$ & 0.130 & 0.159 \\
\hline $\mathrm{P}(\mathrm{ppm})$ (available) & 23.49 & 27.16 \\
\hline $\mathrm{K} \%($ total $)$ & 0.62 & 0.63 \\
\hline $\mathrm{K}(\mathrm{ppm})$ (available) & 916.46 & 943.68 \\
\hline \multicolumn{3}{|c|}{ Soluble cations and anions (ppm) } \\
\hline $\mathrm{Mn}^{++}$ & 8.2 & 9.5 \\
\hline $\mathrm{Fe}^{++}$ & 9.8 & 9.2 \\
\hline $\mathrm{Zn}^{++}$ & 2.5 & 2.3 \\
\hline $\mathrm{Ca}^{++}$ & 182.4 & 187.4 \\
\hline $\mathrm{Mg}^{++}$ & 48.60 & 50.58 \\
\hline $\mathrm{K}^{+}$ & 46.80 & 52.26 \\
\hline $\mathrm{Na}^{+}$ & 201.94 & 204.24 \\
\hline $\mathrm{Cl}^{-}$ & 231.82 & 261.64 \\
\hline $\mathrm{Co}_{3}^{--}$ & 0.00 & 0.00 \\
\hline $\mathrm{H} \mathrm{Co}_{3}^{-}$ & 357.46 & 378.20 \\
\hline $\mathrm{SO}_{4}^{--}$ & 516.48 & 490.08 \\
\hline \multicolumn{3}{|c|}{ Particle size distribution (Mechanical analysis) } \\
\hline Course sand \% & 8.25 & 7.14 \\
\hline Find sand \% & 27.32 & 26.46 \\
\hline Silt $\%$ & 14.22 & 13.24 \\
\hline Clay $\%$ & 50.21 & 53.16 \\
\hline Texture grade & Clay & Clay \\
\hline
\end{tabular}

Microelements were applied twice as foliar spray; it began at the beginning of flowering and 15 days later in form of Zinc Sulphate $\left(\mathrm{Zn} \mathrm{So} \cdot \mathrm{SH}_{2} \mathrm{O}\right)$, Manganese Sulphate $\left(\mathrm{Mn} \mathrm{So} 4.4 \mathrm{H}_{2} \mathrm{O}\right)$ and Ferrous Sulphate $\left(\mathrm{Fe} \mathrm{So} 4.7 \mathrm{H}_{2} \mathrm{O}\right)$ for micro elements under study using Gelatine Powder as a wetting agent to be sure that the solution mostly covered the green parts, the spray solution volume was $200 \mathrm{~L} /$ fed using a hand operated compressed air. The application was carried out between 09:00 and 11:00 a.m. The control treatment received water spray only.

The preceding winter crop in the two seasons was Egyptian clover (Trifolium alexandrinum, L.) as a catch crop. Experiments were planted on $26^{\text {th }}$ and $24^{\text {th }}$ of March in the first and the second seasons, respectively. Cotton planting was done by the local method of dibbling 5 to 7 seeds in each hill by hand with distance between hills was $20 \mathrm{~cm}$ apart and after 35 days of sowing thinning was carried out in order to maintain better two seedlings per hill $(70000$ cotton plants/fed). The experimental design was split plot design in four replications. The two Egyptian cotton cultivars were randomly assigned for main plots and the eight micronutrient treatments of zinc, manganese and iron foliar application were randomly assigned for sub-plots. The sub plot area was $12.6 \mathrm{~m}^{2}$ and contained six ridges of $3.5 \mathrm{~m}$ long and $60 \mathrm{~cm}$ apart. Phosphorous fertilizer was applied at a rate of $22.5 \mathrm{~kg} \mathrm{P} \mathrm{P}_{2} /$ fed in form of calcium super phosphate $\left(12.5 \% \mathrm{P}_{2} \mathrm{O}_{5}\right)$ after ridging and before planting in each season. Nitrogen fertilizer was applied at a rate of $66 \mathrm{~kg} \mathrm{~N} / \mathrm{fed}$ as ammonium nitrate $(33 \% \mathrm{~N})$ and divided into two equal parts and applied side dressed before the first and second irrigations in each season. Potassium fertilizer was applied in form of potassium sulphate $\left(48 \% \mathrm{~K}_{2} \mathrm{O}\right)$ at a rate of $24 \mathrm{~kg} \mathrm{~K}_{2} \mathrm{O} /$ fed in one dose before the second irrigation in each season. Pest and weed management were conducted as needed during the growing season, according to local practice performed at the experimental station. The first irrigation was applied after 21 day from planting irrigation, while the other irrigations were given at 15-day interval. Hand hoeing was carried out three times during the season before the first, second and third irrigations, respectively. All recommended cultural practices for growing cotton according to Agricultural Research Center recommendation were done properly.

\section{Traits studied:}

\section{A- Growth, yield components and yield:}

In both season ten plants were randomly chosen from the two center ridges of each sup-plot to determine:

1) Plant height $(\mathrm{cm})$. The plant height was measured in $\mathrm{cm}$, from the cotyledonary node to the top of the plant at harvest and average was computed.

2) Number of sympodial branches/plant at harvest.

3) Number of open bolls/plant. It was calculated by counting the open bolls/plant on the above the representative plants before the first and second picking.

4) Seed cotton yield/plant (g). It was estimate from the above ten representative plants.

5) Boll weight $(\mathrm{g})$. It was calculated from the following formula:

Boll weight $(\mathrm{g})=\frac{\text { Seed cotton yield } / \text { plant }(\mathrm{g})}{\text { No. of open bolls } / \text { plant at harvest }}$

6) Lint percentage: The all seed cotton obtained from ten representative plants were ginned separately treatment wise with a hand ginning. Lint \% was calculated by using the following formula:

Lint percentage $(\%)=\frac{\text { Weight of lint }(\mathrm{g})}{\text { Weight of seed cotton }(\mathrm{g})} \times 100$

7) Lint cotton yield/plant (g). It was estimate from the following formula:

Lint cotton yield $/$ plant $(g)=\frac{\text { Seed cotton yield } / \text { plant }(g) \times \text { lint } \%}{100}$

8) Seed index ( $\mathrm{g})$. It was estimated from the average of 100 -seed weight (g) was taken at random after ginning.

9) Seed cotton yield/feddan (kentar): It was estimated and transformed to kentar/feddan (feddan $=4200 \mathrm{~m}^{2}$ and kentar $=157.5 \mathrm{~kg}$ ), the 
seed cotton yield was picked twice; first hand picking took place on 19 and 22 September and final picking on 8 and 15 October in 2015 and 2016, respectively, in picking from whole plants of two center ridges (including 10 plant subsamples) were selected to be picked in order to avoid border effect.

10) Lint cotton yield/fed (kentar): It was estimated and transformed to kentar/fed (kentar $=50 \mathrm{~kg}$ ), it was calculated from the following equation:

Lint cotton yield $/$ fed $($ ken $)=\frac{\text { Seed cotton yield } / \text { fed }(\text { ken }) \times 157.5 \times \text { Lint } \%}{50 \times 100}$.

\section{B- Fiber properties:}

1) Upper half mean length (mm).

2) Length uniformity index $(\%)$.

3) Fiber strength ( $g /$ tex $)$.

4) Fiber elongation percentage (\%).

5) Micronaire value.

6) Fiber maturity ratio (\%)

7) Fiber reflectance $(\mathrm{Rd} \%)$.

8) Fiber yellowness degree $\left({ }^{+} b\right)$.

The measurement of some fiber technological properties were determined at Cotton Technology Research Division, Cotton Research Institute, Giza, Egypt, at a constant relative humidity $65 \%( \pm 2)$ and temperature $21 \mathrm{C}^{\mathrm{O}}( \pm 2)$. HVI instrument system was used to determine fiber length at Upper half means length (UHML), fiber uniformity index, fiber strength ( $\mathrm{g} / \mathrm{tex})$, fiber elongation \%, fiber reflectance $(\mathrm{Rd} \%)$ and fiber yellowness degree $\left({ }^{+} \mathrm{b}\right)$ according to (A.S.T.M., D:4605-1986.). While micronaire value and fiber maturity ratio were determined using micromate instrument according to (A.S.T.M., D: 3818 - 1986).

\section{Statistical analysis:}

The analysis of variance was carried out according to the procedure described by Gomez and Gomez (1984). Data were statistically analyzed according to using the MSTAT-C Statistical Software Package (Michigan State University, 1983). Where the F-test showed significant differences among mean of treatments, the least significant difference (L.S.D.) test at 0.05 level was used to compare between means.

\section{Results and Discussion}

\section{A- Growth, yield and yield components:}

\section{Effect of Egyptian cotton cultivars:}

Results presented in Table 2 revealed that the differences between the studied two Egyptian cotton cultivars, i.e. Giza 86 and Giza 88 in all growth traits, plant characteristics, yield components and yield in the both seasons were significant. These results revealed that Giza 86 cultivar recorded the greatest values of plant height $(136.0$ and $147.8 \mathrm{~cm})$, No. of sympodial branches/plant (14.2 and 15.6 branches),
No. of open bolls/plant (14.6 and 14.1 bolls), seed cotton yield/plant (46.32 and $41.11 \mathrm{~g}$ ), boll weight ( 3.13 and $2.90 \mathrm{~g})$, lint percentage (38.50 and 38.03 $\%)$, lint cotton yield/plant (18.00 and $15.71 \mathrm{~g})$, seed index (9.93 and $9.65 \mathrm{~g})$, seed cotton yield/fed (10.907 and $10.628 \mathrm{ken}$ ) and lint cotton yield/fed (13.301 and $12.776 \mathrm{ken})$ in the first and second seasons, respectively. These differences may be due to the genetic differences between the two Egyptian cotton cultivars. The superiority of Giza 86 cultivar in seed and lint cotton yield/fed over the Giza 88 cultivar might be due to the increase in growth and yield components, namely, plant height $(\mathrm{cm})$, No. of sympodial branches/plant, No. of open bolls/plant, seed cotton yield/plant $(\mathrm{g})$, boll weight $(\mathrm{g})$, lint percentage $(\%)$, lint cotton yield/plant $(\mathrm{g})$ and seed index $(\mathrm{g})$. These results are in harmony with those reported by El-Kashlan et al., 1995; Nichols et al., 2004; Sawan et al., 2006; Elayan, 2008; Ali et al., 2009; Saleem et al., 2010; Ali and Hameed 2011; Ayissa and Kebede 2011; Baraich et al., 2012; Abdallah and Hanaa, 2013; Aslam et al., 2013; Jahedi et al., 2013; Eleyan et al., 2014; Eleyan et al., 2015 and Mahdy et al., 2017.

Effect of foliar spray by microelements:

Data recorded in Table 2 indicated that the all growth traits, plant characteristics, yield components and yield of cotton were significantly increased by application $\mathrm{Zn}, \mathrm{Mn}$ and $\mathrm{Fe}$ and their combination compared to without microelements application during the 2015 and 2016 seasons. Results revealed that microelements foliar spray using mixture of $\mathrm{Zn}+$ $\mathrm{Mn}+\mathrm{Fe}$ treatment was the most effective treatment and recorded the maximum values for plant height (126.9 and $139.1 \mathrm{~cm})$, No. of sympodial branches/plant (14.4 and 14.8 branches), No. of open bolls/plant (15.9 and 15.3 bolls), seed cotton yield/plant (52.43 and $46.38 \mathrm{~g}$ ), boll weight (3.27 and $3.01 \mathrm{~g}$ ), lint percentage (39.31 and $37.58 \%$ ), lint cotton yield/plant (20.79 and $17.56 \mathrm{~g})$, seed index (9.94 and $9.59 \mathrm{~g})$, seed cotton yield/fed (11.652 and $10.952 \mathrm{ken})$ and lint cotton yield/fed (14.508 and 13.057 ken) during the first and second seasons respectively. In 2015 season, the seed cotton yield/fed increased by $28.10,9.78,15.80,34.27$, $41.20,22.16$ and $48.24 \%$ when microelements application of $\mathrm{Zn}, \mathrm{Mn}, \mathrm{Fe}, \mathrm{Zn}+\mathrm{Mn}, \mathrm{Zn}+\mathrm{Fe}, \mathrm{Mn}+$ $\mathrm{Fe}$ and $\mathrm{Zn}+\mathrm{Mn}+\mathrm{Fe}$ respectively over the control treatment (no microelements applied). Similar results were noticed in 2016 season, the seed cotton yield/fed increased with by about $24.92,14.91,10.55$, $31.41,37.03,18.24$ and $39.77 \%$, respectively. The increase in cotton yield and its components traits with the applying of microelements foliar spray especially $\mathrm{Zn}+\mathrm{Mn}+\mathrm{Fe}$ treatment may be due to the synergetic role of microelements in improving directly or indirectly photosynthesis, vital processes in plant such as respiration, protein synthesis, reproduction phase, biochemical and physiological activities. The superiority of microelements foliar spray using 
mixture of $\mathrm{Zn}+\mathrm{Mn}+\mathrm{Fe}$ treatment in seed and lint cotton yield/fed might be due to the increase in growth and yield components, namely, plant height (cm), No. of sympodial branches/plant, No. of open bolls/plant, seed cotton yield/plant $(\mathrm{g})$, boll weight $(\mathrm{g})$, lint percentage $(\%)$, lint cotton yield/plant $(\mathrm{g})$ and seed index $(\mathrm{g})$. Many investigators came out with similar results as El-Kashlan et al., 1995; Soomro et al., 2000; Rezaei and Malakouti, 2001; Mamatha 2007; Sawan et al., 2007; Elayan, 2008; Sawan et al., 2008; Ali et al., 2011; Abdallah and Hanaa, 2013; Radhika et al., 2013; Yaseen et al., 2013; Eleyan et al., 2014; Khalid et al., 2015; Singh et al., 2015 and Emara, 2016.

\section{Effect of the interaction:}

The significant effect of the interaction between Egyptian cotton cultivars and foliar spray by microelements treatments obtained for some yield and yield components of cotton namely, No. of open bolls/plant, seed cotton yield/plant $(\mathrm{g})$, boll weight (g), lint cotton yield/plant $(\mathrm{g})$ and seed cotton yield/fed (ken) and lint cotton yield/fed (ken) during the 2015 and 2016 seasons. On the other hand, plant height $(\mathrm{cm})$, No. of sympodial branches/plant, lint \% and seed index $(\mathrm{g})$ were not affected by the interaction (Table 2). Planting Egyptian cotton cultivar of Giza 86 which foliar spray by mixed micronutrients of $\mathrm{Zn}+\mathrm{Mn}+\mathrm{Fe}$ treatment significantly recorded the highest values of No. of open bolls/plant (17.6 and 16.9 bolls), seed cotton yield/plant (62.83 and $54.25 \mathrm{~g}$ ), boll weight (3.57 and $3.21 \mathrm{~g})$, lint cotton yield/plant (25.77 and $21.31 \mathrm{~g})$, seed cotton yield/fed (13.158 and $12.672 \mathrm{ken})$ and lint cotton yield/fed (17.002 and $05.679 \mathrm{ken})$ in the first and second seasons, respectively. On the other hand, sowing the Egyptian cotton cultivar of Giza 88 under without micronutrients application gave the lowest values of No. of open bolls/plant (10.8 and 11.2 bolls), seed cotton yield/plant (23.76 and 25.98 $\mathrm{g})$, boll weight $(2.20$ and $2.32 \mathrm{~g})$, lint cotton yield/plant $(7.65$ and $8.06 \mathrm{~g}$ ), seed cotton yield/fed (6.866 and $7.515 \mathrm{ken})$ and lint cotton yield/fed (6.962 and $7.343 \mathrm{ken}$ ) during the both seasons, respectively. Similar results were also reported by El-Kashlan $\boldsymbol{e t}$ al., 1995; Elayan, 2008; Abdallah and Hanaa, 2013 and Eleyan et al., 2014.

\section{B- Fiber properties:}

\section{Effect of Egyptian cotton cultivars:}

Regarding data in Table 3 it could be noticed that there were significant differences among the two Egyptian cotton cultivars on all fiber properties on all fiber properties traits during the both seasons. The highest mean values of upper half mean length $(34.45$ and $34.05 \mathrm{~mm})$, length uniformity index $(85.12$ and $86.89 \%$ ), fiber strength (43.91 and $43.50 \mathrm{~g} / \mathrm{tex})$ and fiber yellowness degree (12.23 and 12.64) in 2015 and 2016 seasons, respectively were recorded for the Egyptian cotton cultivar Giza 88. Likewise, the highest mean values of fiber elongation percentage (7.25 and 7.24\%), micronaire value (4.21 and 4.20), fiber maturity ratio $(85.52$ and $85.46 \%)$ and fiber reflectance (72.28 and 70.19) in the first and second seasons, respectively were gained from the Egyptian cotton cultivar Giza 86. These results could be attributed to the best genetically structure of the extra-long staple cotton viz. Giza 88 which characterized the best fiber properties especially upper half mean length, length uniformity index, fiber strength and fiber yellowness degree. Many investigators came out with similar results as ElKashlan et al., 1995; Nichols et al., 2004; Sawan et al., 2006; El-Sayed and Sanad 2007; Gururajan 2007; Elayan, 2008; Saleem et al., 2010; Alitabar et al., 2012; Abdallah and Hanaa, 2013; El Messiry and Abd-Ellatif 2013; Ibrahim, 2013; Jahedi et al., 2013; Eleyan et al., 2014 and Eleyan et al., 2015.

\section{Effect of foliar spray by microelements:}

Results presented in Table 3 revealed that the differences between the studied eight microelements, i.e. without microelements application, $\mathrm{Zn}, \mathrm{Mn}, \mathrm{Fe}$, $\mathrm{Zn}+\mathrm{Mn}, \mathrm{Zn}+\mathrm{Fe}, \mathrm{Mn}+\mathrm{Fe}$ and $\mathrm{Zn}+\mathrm{Mn}+\mathrm{Fe}$ treatments in fiber properties of cotton in 2015 and 2016 seasons were significant except, color attributes values (fiber reflectance and fiber yellowness degree) were not significant. These results revealed that application of combined of $\mathrm{Zn}+\mathrm{Mn}+\mathrm{Fe}$ treatment gave significantly the highest values of upper half mean length (33.77 and $33.88 \mathrm{~mm})$, length uniformity index (87.05 and $87.66 \%)$, fiber strength (44.69 and $43.47 \mathrm{~g} /$ tex), fiber elongation percentage (7.61 and $7.15 \%)$, micronaire value (4.20 and 4.20$)$ and fiber maturity ratio (86.56 and $86.19 \%$ ) in the first and second seasons, respectively. The increase in fiber properties of cotton with the application of microelements especially $\mathrm{Zn}+\mathrm{Mn}+\mathrm{Fe}$ treatment may be due to the synergetic role of microelements in improving directly or indirectly photosynthesis, vital processes in plant such as respiration, protein synthesis, reproduction phase, biochemical and physiological activities. Many investigators came out with similar results as El-Kashlan et al., 1995; Sawan et al., 2007; Elayan, 2008; Sawan et al., 2008; Abdallah and Hanaa, 2013; Radhika et al., 2013; Yaseen et al., 2013; Eleyan et al., 2014 and Emara, 2016.

\section{Effect of the interaction:}

Results in Table 3 revealed that some fiber properties of Egyptian cotton, i.e. upper half mean length, length uniformity index, fiber strength and fiber maturity ratio were significantly affected by the interaction between Egyptian cotton cultivars and foliar spray by microelements treatments during 2015 and 2016 seasons. But, fiber elongation \%, micronaire value, fiber reflectance and fiber yellowness degree were not significantly affected in the two seasons. 
Table 2. Effect of Egyptian cotton cultivars, microelements foliar spray and their interaction on plant height (cm), No. of sympodial branches/plant, No. of open bolls/plant, seed cotton yield/plant (g), boll weight $(\mathrm{g})$, lint percentage $(\%)$, lint cotton yield/plant $(\mathrm{g})$, seed index (g), seed cotton yield (Ken/fed) and lint cotton yield (Ken/fed) of cotton during 2015 and 2016 seasons.

\begin{tabular}{|c|c|c|c|c|c|c|c|c|c|c|c|c|c|c|c|c|c|c|c|c|c|}
\hline \multirow[t]{2}{*}{ Treatment } & \multirow{2}{*}{$\begin{array}{c}\text { Trait } \\
\text { Season } \\
\end{array}$} & \multicolumn{2}{|c|}{$\begin{array}{c}\text { Plant height } \\
\text { (cm) }\end{array}$} & \multicolumn{2}{|c|}{$\begin{array}{c}\text { No. of } \\
\text { sympodial } \\
\text { branches/plant }\end{array}$} & \multicolumn{2}{|c|}{$\begin{array}{l}\text { No. of open } \\
\text { bolls/plant }\end{array}$} & \multicolumn{2}{|c|}{$\begin{array}{c}\text { Seed cotton } \\
\text { yield/plant (g) }\end{array}$} & \multicolumn{2}{|c|}{ Boll weight (g) } & \multicolumn{2}{|c|}{$\begin{array}{c}\text { Lint } \\
\text { percentage } \\
(\%)\end{array}$} & \multicolumn{2}{|c|}{$\begin{array}{c}\text { Lint cotton } \\
\text { yield/plant (g) }\end{array}$} & \multicolumn{2}{|c|}{ Seed index $(g)$} & \multicolumn{2}{|c|}{$\begin{array}{c}\text { Seed cotton } \\
\text { yield (Ken/fed) }\end{array}$} & \multicolumn{2}{|c|}{$\begin{array}{c}\text { Lint cotton } \\
\text { yield }(\text { Ken/fed })\end{array}$} \\
\hline & & 2015 & 2016 & 2015 & 2016 & 2015 & 2016 & 2015 & 2016 & 2015 & 2016 & 2015 & 2016 & 2015 & 2016 & 2015 & 2016 & 2015 & 2016 & 2015 & 2016 \\
\hline \multicolumn{22}{|c|}{ Cotton verities } \\
\hline \multirow{2}{*}{\multicolumn{2}{|c|}{$\begin{array}{l}\text { Giza } 86 \\
\text { Giza } 88\end{array}$}} & 136.0 & 147.8 & 14.2 & 15.6 & 14.6 & 14.1 & 46.32 & 1 & 3.13 & 2.90 & 38.50 & 38.03 & 8.00 & 15.71 & 9.93 & 9.65 & 0.907 & 10.628 & 13.301 & 12.776 \\
\hline & & 106.5 & 117.2 & 12.8 & 12.2 & 13.2 & 12.7 & 36.28 & 3.41 & 2.74 & 2.63 & 34.98 & 34.11 & 12.77 & 11.45 & 8.70 & 8.42 & 8.734 & 8.507 & 9.674 & 9.163 \\
\hline \multicolumn{2}{|c|}{ L.S.D at 5\% } & 5.6 & 46 & 0.7 & 0.9 & 05 & 06 & 362 & 413 & 0.12 & 0.15 & 0.98 & 1.15 & 2.23 & 2.38 & 0.22 & 0.31 & 0.491 & 0.653 & 0.625 & 0.752 \\
\hline \\
\hline \multicolumn{2}{|c|}{$\begin{array}{l}\text { Microelements foliar s } \\
\text { Control }\end{array}$} & 115.8 & 5 & 11.7 & 12.9 & 11 & 1 & 2 & 9 & 2.41 & 10 & 3.78 & 60 & 25 & 3 & 51 & 51 & 60 & 36 & 12 & 19 \\
\hline & 122.5 & 133.0 & 13.8 & 14.0 & 1 & 1 & & & & & 36.79 & 36.42 & & & & 09 & & 89 & 1.738 & 1.294 \\
\hline \multicolumn{2}{|l|}{ Mn } & 117.4 & 128.6 & 13.1 & 13.5 & 13.1 & 12.3 & 36.49 & 9 & 2.80 & 2.61 & 35.70 & 35.17 & 3.06 & 11.30 & 8.94 & 8.80 & 8.629 & 9.004 & 9.732 & 10.030 \\
\hline \multicolumn{2}{|l|}{$\mathrm{Fe}$} & 118.2 & 129.3 & 13.2 & 13.7 & 13.3 & 12.4 & 38.40 & 33.43 & 2.89 & 2.70 & 35.94 & 35.61 & 13.84 & 11.94 & 9.05 & 8.81 & 9.102 & 8.663 & 10.340 & 9.746 \\
\hline \multicolumn{2}{|c|}{$\mathbf{Z n}+\mathbf{M n}$} & 123.7 & 135.7 & 14.0 & 14.2 & 14.5 & 14.5 & 45.17 & 41.86 & 3.10 & 2.89 & 37.39 & 36.99 & 17.03 & 15.58 & 9.64 & 9.20 & 10.554 & 10.297 & 12.526 & 12.076 \\
\hline $\mathrm{Zn}+\mathrm{Fe}$ & & 124.4 & 136.8 & 14.0 & 14.4 & 15.4 & 14.9 & 48.79 & 44.07 & 3.16 & 2.95 & 38.90 & 37.23 & 19.09 & 16.52 & 9.76 & 9.31 & 11.098 & 10.738 & 13.658 & 12.695 \\
\hline $\mathbf{M n}+\mathbf{F}$ & & 121.0 & 131.4 & 13.5 & 13.8 & 13.7 & 12.9 & 40.15 & 35.53 & 2.93 & 2.75 & 36.12 & 35.95 & 14.57 & 12.83 & 9.15 & 8.99 & 9.602 & 9.265 & 10.986 & 10.543 \\
\hline$\underline{\mathbf{Z n}}+\mathbf{M}$ & $\mathrm{n}+\mathrm{Fe}$ & 126.9 & 139.1 & 14.4 & 14.8 & 15.9 & 15.3 & 52.43 & 46.38 & 3.27 & 3.01 & 39.31 & 37.58 & 20.79 & 17.56 & 9.94 & 9.59 & 11.652 & 10.952 & 14.508 & 13.057 \\
\hline L.S.D a & $5 \%$ & 11.5 & 10.1 & 1.3 & 1.7 & 1.1 & 1.3 & 6.95 & 8.81 & 0.26 & 0.32 & 1.86 & 2.12 & 4.02 & 3.86 & 0.46 & 0.65 & 0.945 & 1.353 & 1.192 & 1.483 \\
\hline Cottol & verities X Mi & elemen & fertili & zation ir & eraction & & & & & & & & & & & & & & & & \\
\hline & Control & 129.2 & 142.6 & 12.2 & 14.1 & 11.7 & 11.4 & 30.65 & 28.20 & 2.62 & 2.47 & 35.36 & 36.18 & 10.84 & 10.20 & 8.78 & 9.02 & 8.853 & 8.156 & 9.861 & 9.295 \\
\hline & $\mathbf{Z n}$ & 137.8 & 148.3 & 14.6 & 15.7 & 14.8 & 14.1 & 45.73 & 41.17 & 3.09 & 2.92 & 38.72 & 38.27 & 17.71 & 15.76 & 10.11 & 9.75 & 11.214 & 10.895 & 13.677 & 13.134 \\
\hline & Mn & 130.5 & 144.6 & 13.7 & 15.2 & 13.2 & 12.3 & 38.02 & 34.32 & 2.88 & 2.79 & 37.42 & 37.08 & 14.23 & 12.73 & 9.43 & 9.38 & 9.152 & 9.914 & 10.788 & 11.580 \\
\hline & $\mathrm{Fe}$ & 132.1 & 145.0 & 13.8 & 15.3 & 13.5 & 12.5 & 40.77 & 35.13 & 3.02 & 2.81 & 37.64 & 37.54 & 15.35 & 13.19 & 9.55 & 9.42 & 9.785 & 9.152 & 11.602 & 10.822 \\
\hline & $\mathbf{Z n}+\mathbf{M n}$ & 138.9 & 151.2 & 14.8 & 15.8 & 15.3 & 15.7 & 51.71 & 47.41 & 3.38 & 3.02 & 39.57 & 38.75 & 20.46 & 18.37 & 10.46 & 9.86 & 11.946 & 11.708 & 14.890 & 14.291 \\
\hline & $\mathbf{Z n}+\mathbf{F e}$ & 140.2 & 152.0 & 14.8 & 16.2 & 16. & 16.2 & 57.11 & 50.06 & 3. & 3.09 & 40.25 & 39.11 & 22.99 & 19.58 & 10.62 & 9.99 & 12.502 & 12.467 & 15.851 & 15.359 \\
\hline & $\mathbf{M n}+\mathbf{F e}$ & 135.6 & 146.2 & 14.2 & 15.6 & 14 & 13. & 43.74 & 38.30 & 3. & 2.88 & 37.98 & 38.01 & 16.61 & 14.56 & 9.67 & 9.56 & 10.643 & 10.063 & 12.733 & 12.049 \\
\hline & $\mathbf{Z n}+\mathbf{M n}$ & 143.3 & 152.4 & 15.3 & 16.8 & 17 & & & & 3. & 3.21 & 41.02 & 39.28 & 25.77 & 21.31 & 10.82 & 10.23 & 13.158 & 12.672 & 17.002 & 15.679 \\
\hline & Control & 102.4 & 110.4 & 11.2 & 11.7 & 10.8 & 11. & 23.76 & 25.98 & 2.20 & 2.32 & 32.19 & 31.02 & 7.65 & 8.06 & 8.43 & 8.00 & 6.866 & 7.515 & 6.962 & 7.343 \\
\hline & $\mathbf{Z n}$ & 107.2 & 117.6 & 13.0 & 12.2 & 13.5 & 12.7 & $\mathbf{3 7 . 8 0}$ & 34.29 & 2.80 & 2.70 & 34.86 & $\mathbf{3 4 . 5 7}$ & 13.18 & 11.85 & 8.77 & 8.43 & 8.924 & 8.682 & 9.799 & 9.454 \\
\hline & Mn & 104.2 & 112.5 & 12.5 & 11.8 & 12.9 & 12.2 & 34.96 & 29.65 & 2.71 & 2.43 & 33.98 & 33.26 & 11.88 & 9.86 & 8.44 & 8.21 & 8.105 & 8.093 & 8.675 & 8.479 \\
\hline & $\mathrm{Fe}$ & 104.3 & 113.5 & 12.6 & 12.0 & 13.1 & 12.3 & 36.03 & 31.73 & 2.75 & 2.58 & 34.23 & 33.67 & 12.33 & 10.68 & 8.55 & 8.2 & 8.418 & 8.174 & 9.077 & 8.669 \\
\hline Giza 88 & $\mathbf{Z n}+\mathbf{M n}$ & 108.5 & 120.1 & 13.2 & 12.5 & 13.7 & 13.2 & 38.63 & 36.30 & 2.82 & 2.75 & 35.21 & 35.23 & 13.60 & 12.79 & 8.82 & 8.54 & 9.162 & 8.886 & 10.162 & 9.861 \\
\hline & $\mathbf{Z n}+\mathbf{F e}$ & 108.6 & 121.5 & 13.2 & 12.6 & 14.0 & 13.6 & 40.46 & 38.08 & 2.89 & 2.80 & 37.55 & 35.35 & 15.19 & 13.46 & 8.89 & 8.63 & 9.693 & 9.008 & 11.465 & 10.031 \\
\hline & $\mathbf{M n}+\mathbf{F e}$ & 106.3 & 116.5 & 12.8 & 12.0 & 13.2 & 12.5 & 36.56 & 32.75 & 2.77 & 2.62 & 34.26 & 33.88 & 12.53 & 11.10 & 8.63 & 8.41 & 8.561 & 8.467 & 9.239 & 9.036 \\
\hline & $\mathbf{Z n}+\mathbf{M n}+\mathbf{F e}$ & 110.5 & 125.7 & 13.5 & 12.8 & 14.2 & 13.7 & 42.03 & 38.50 & 2.96 & 2.81 & 37.59 & 35.88 & 15.80 & 13.81 & 9.05 & 8.95 & 10.146 & 9.232 & 12.014 & 10.434 \\
\hline L.S.D a & $5 \%$ & N.S. & N.S. & N.S. & N.S. & 1.6 & 1.8 & 9.83 & 12.46 & 0.37 & 0.45 & N.S. & N.S. & 5.69 & 5.46 & N.S. & N.S. & 1.336 & 1.913 & 1.686 & 2.097 \\
\hline
\end{tabular}


Table 3. Effect of Egyptian cotton cultivars, microelements foliar spray and their interaction on upper half mean length (mm), length uniformity index (\%), fiber strength $(\mathrm{g} / \mathrm{tex})$, fiber elongation percentage (\%),micronaire value, fiber maturity ratio (\%), fiber reflectance $(\mathrm{Rd} \%)$ and fiber yellowness degree $(+\mathrm{b})$ of cotton fibers during 2015 and 2016 seasons.

\begin{tabular}{|c|c|c|c|c|c|c|c|c|c|c|c|c|c|c|c|c|c|}
\hline \multirow[t]{2}{*}{ Treatment } & \multirow{2}{*}{$\begin{array}{c}\text { Trait } \\
\text { Season } \\
\end{array}$} & \multicolumn{2}{|c|}{$\begin{array}{c}\text { Upper half mean } \\
\text { length }(\mathrm{mm})\end{array}$} & \multicolumn{2}{|c|}{$\begin{array}{c}\text { Length } \\
\text { uniformity index } \\
(\%)\end{array}$} & \multicolumn{2}{|c|}{$\begin{array}{l}\text { Fiber strength } \\
(\mathrm{g} / \mathrm{tex})\end{array}$} & \multicolumn{2}{|c|}{$\begin{array}{l}\text { Fiber elongation } \\
\text { percentage }(\%)\end{array}$} & \multicolumn{2}{|c|}{ Micronaire value } & \multicolumn{2}{|c|}{$\begin{array}{l}\text { Fiber maturity } \\
\quad \text { ratio }(\%)\end{array}$} & \multicolumn{2}{|c|}{$\begin{array}{l}\text { Fiber reflectance } \\
(\text { Rd \%) }\end{array}$} & \multicolumn{2}{|c|}{$\begin{array}{c}\text { Fiber yellowness } \\
\text { degree }\left({ }^{+} \mathbf{b}\right)\end{array}$} \\
\hline & & 2015 & 2016 & 2015 & 2016 & 2015 & 2016 & 2015 & 2016 & 2015 & 2016 & 2015 & 2016 & 2015 & 2016 & 2015 & 2016 \\
\hline \multicolumn{18}{|c|}{ Cotton verities } \\
\hline \multicolumn{2}{|c|}{ Giza 86} & 31.77 & 32.11 & 85.12 & 84.73 & 42.16 & 42.03 & 7.25 & 7.24 & 4.21 & 4.20 & 85.52 & 85.46 & 72.28 & 70.19 & 9.13 & 8.97 \\
\hline \multicolumn{2}{|l|}{ Giza 88} & 34.45 & 34.05 & 86.12 & 86.89 & 43.91 & 43.50 & 6.07 & 6.16 & 3.80 & 3.85 & 82.82 & 82.19 & 59.83 & 58.17 & 12.23 & 12.64 \\
\hline \multicolumn{2}{|c|}{ L.S.D at 5\% } & 0.53 & 0.49 & 0.23 & 0.19 & 0.26 & 0.35 & 0.32 & 0.42 & 0.11 & $\mathbf{0 . 1 3}$ & 0.66 & 0.59 & 1.88 & 2.13 & 1.25 & 1.52 \\
\hline \multicolumn{18}{|c|}{ Microelements fertilization } \\
\hline & 32.12 & 31.64 & 84.01 & 83.15 & 40.64 & 41.00 & 5.48 & 5.99 & 3.59 & 3.71 & 81.42 & 81.11 & 59.02 & 59.88 & 12.08 & 11.90 \\
\hline \multicolumn{2}{|l|}{$\mathrm{Zn}$} & 33.46 & 33.27 & 85.59 & 85.97 & 43.12 & 43.08 & 6.26 & 6.52 & 4.05 & 4.07 & 84.79 & 84.07 & 67.20 & 64.67 & 10.52 & 10.59 \\
\hline \multicolumn{2}{|l|}{ Mn } & 32.55 & 32.76 & 85.10 & 85.12 & 42.63 & 42.54 & 6.44 & 6.67 & 3.87 & 3.96 & 82.51 & 82.61 & 62.12 & 60.76 & 11.08 & 11.32 \\
\hline \multicolumn{2}{|l|}{$\mathbf{F e}$} & 32.70 & 32.94 & 85.16 & 85.26 & 42.72 & 42.66 & 6.62 & 6.75 & 3.98 & 3.98 & 83.33 & 82.91 & 63.69 & 61.69 & 10.89 & 11.26 \\
\hline \multicolumn{2}{|c|}{$\mathbf{Z n}+\mathbf{M n}$} & 33.50 & 33.48 & 86.03 & 86.60 & 43.48 & 43.22 & 6.46 & 6.72 & 4.13 & 4.12 & 85.17 & 85.06 & 68.98 & 66.77 & 10.22 & 10.34 \\
\hline \multicolumn{2}{|c|}{$\mathbf{Z n}+\mathbf{F e}$} & 33.72 & 33.60 & 86.61 & 87.11 & 44.18 & 43.33 & 7.10 & 6.77 & 4.17 & 4.15 & 86.03 & 85.24 & 70.34 & 67.76 & 10.04 & 10.18 \\
\hline \multicolumn{2}{|c|}{$\mathrm{Mn}+\mathrm{Fe}$} & 33.06 & 33.10 & 85.44 & 85.60 & 42.85 & 42.84 & 7.30 & 7.06 & 4.06 & 4.04 & 83.58 & 83.44 & 64.93 & 63.07 & 10.69 & 10.96 \\
\hline \multicolumn{2}{|c|}{$\underline{\mathrm{Zn}}+\mathrm{Mn}+\mathrm{Fe}$} & 33.77 & 33.88 & 87.05 & 87.66 & 44.69 & 43.47 & 7.61 & 7.15 & 4.20 & 4.20 & 86.56 & 86.19 & 72.17 & 68.87 & 9.93 & 9.94 \\
\hline L.S.D at & & 0.88 & 0.92 & 0.48 & 0.41 & 0.48 & 0.73 & 0.63 & 0.80 & 0.23 & 0.25 & 1.28 & 1.34 & N.S. & N.S. & N.S. & N.S. \\
\hline Cotton v & rities X Mi & ents ferti & zation int & eraction & & & & & & & & & & & & & \\
\hline & Control & 31.21 & 30.27 & 83.15 & 82.19 & 40.15 & 39.77 & 5.83 & 6.25 & 3.92 & 3.79 & 83.89 & 83.06 & 66.77 & 64.89 & 9.89 & 10.05 \\
\hline & Zn & 32.08 & 32.39 & 85.15 & 84.35 & 42.25 & 42.37 & 6.67 & 7.01 & 4.22 & 4.25 & 85.34 & 85.99 & 73.86 & 70.84 & 9.05 & 8.66 \\
\hline & Mn & 31.27 & 32.00 & 84.76 & 84.11 & 41.76 & 41.99 & 6.86 & 7.16 & 4.08 & 4.12 & 84.56 & 84.15 & 68.12 & 66.27 & 9.42 & 9.59 \\
\hline & $\mathrm{Fe}$ & 31.29 & 32.11 & 84.79 & 84.26 & 41.88 & 42.05 & 6.99 & 7.29 & 4.11 & 4.13 & 84.78 & 84.36 & 69.56 & 67.53 & 9.25 & 9.53 \\
\hline G & $\mathbf{Z n}+\mathbf{M n}$ & 31.88 & 32.42 & 85.54 & 85.32 & 42.69 & 42.55 & 6.89 & 7.29 & 4.33 & 4.32 & 85.78 & 86.55 & 75.23 & 73.38 & 8.98 & 8.44 \\
\hline & $\mathbf{Z n}+\mathbf{F e}$ & 32.25 & 32.56 & 85.99 & 86.12 & 43.08 & 42.62 & 7.88 & 7.25 & 4.35 & 4.35 & 86.95 & 86.59 & 76.15 & 74.26 & 8.72 & 8.32 \\
\hline & $\mathbf{M n}+\mathbf{F e}$ & 31.88 & 32.25 & 85.11 & 84.32 & 42.03 & 42.23 & 8.15 & 7.81 & 4.25 & 4.22 & 85.01 & 84.87 & 70.98 & 69.15 & 9.15 & 9.04 \\
\hline & $\mathbf{Z n}+\mathbf{M n}+\mathbf{F e}$ & 32.29 & 32.88 & 86.49 & 87.15 & 43.45 & 42.68 & 8.69 & 7.89 & 4.39 & 4.41 & 87.86 & 88.12 & 77.58 & 75.18 & 8.61 & 8.15 \\
\hline & Control & 33.03 & 33.00 & 84.87 & 84.11 & 41.12 & 42.23 & 5.12 & 5.72 & 3.26 & 3.62 & 78.95 & 79.15 & 51.26 & 54.86 & 14.27 & 13.75 \\
\hline & Zn & 34.83 & 34.15 & 86.02 & 87.59 & 43.99 & 43.79 & 5.85 & 6.02 & 3.88 & 3.88 & 84.23 & 82.15 & 60.54 & 58.49 & 11.98 & 12.51 \\
\hline & Mn & 33.83 & 33.52 & 85.43 & 86.12 & 43.50 & 43.08 & 6.02 & 6.18 & 3.65 & 3.80 & 80.45 & 81.07 & 56.12 & 55.25 & 12.73 & 13.05 \\
\hline & $\mathrm{Fe}$ & 34.10 & 33.76 & 85.53 & 86.25 & 43.56 & 43.27 & 6.25 & 6.21 & 3.85 & 3.82 & 81.88 & 81.45 & $\mathbf{5 7 . 8 1}$ & 55.84 & 12.52 & 12.99 \\
\hline Giza 88 & $\mathbf{Z n}+\mathbf{M n}$ & 35.12 & 34.53 & 86.51 & 87.88 & 44.26 & 43.89 & 6.02 & 6.15 & 3.92 & 3.92 & 84.56 & 83.57 & 62.73 & 60.15 & 11.46 & 12.23 \\
\hline & $\mathbf{Z n}+\mathbf{F e}$ & 35.19 & 34.63 & 87.22 & 88.10 & 45.28 & 44.03 & 6.31 & 6.28 & 3.99 & 3.95 & 85.10 & 83.88 & 64.52 & 61.25 & 11.36 & 12.03 \\
\hline & $\mathbf{M n}+\mathbf{F e}$ & 34.23 & 33.95 & 85.77 & 86.88 & 43.67 & 43.44 & 6.44 & 6.30 & 3.86 & 3.86 & 82.14 & 82.01 & 58.88 & 56.99 & 12.23 & 12.87 \\
\hline & $\mathrm{Zn}+\mathrm{Mn}+\mathrm{Fe}$ & 35.25 & 34.88 & 87.61 & 88.17 & 45.92 & 44.25 & 6.52 & 6.41 & 4.01 & 3.98 & 85.26 & 84.26 & 66.75 & 62.56 & 11.25 & 11.72 \\
\hline L.S.D at & & 1.30 & 0.68 & 0.58 & 0.68 & 1.03 & 0.89 & N.S. & N.S. & N.S. & N.S. & 1.81 & 1.90 & N.S. & N.S. & N.S. & N.S. \\
\hline
\end{tabular}


The highest mean values of upper half mean length (35.25 and $34.88 \mathrm{~mm})$, length uniformity index (87.61 and $88.17 \%)$, fiber strength and (45.92 and $44.25 \mathrm{~g} / \mathrm{tex})$ in 2015 and 2016 seasons, respectively were recorded from planting Egyptian cotton cultivar of Giza 88 with foliar spray by mixed micronutrients of $\mathrm{Zn}+\mathrm{Mn}+\mathrm{Fe}$ treatment. Likewise, the highest mean values of fiber maturity ratio $(87.86$ and $88.12 \%$ ) in the both seasons, respectively was recorded from the Egyptian cotton cultivar of Giza 86 under foliar spray of mixed micronutrients of $\mathrm{Zn}+$ $\mathrm{Mn}+\mathrm{Fe}$ treatment. Similar results were also reported by El-Kashlan et al., 1995; Elayan, 2008; Abdallah and Hanaa, 2013 and Eleyan et al., 2014.

\section{Conclusion}

Based on the previous results it could be concluded that, Egyptian cotton Giza 86 cultivar significantly surpassed Giza 88 cultivar in growth, yield and yield components. On the other hand, Giza 88 cultivar significantly surpassed Giza 86 cultivar in fiber properties. Micronutrients foliar application twice of zinc, manganese and iron and their combinations were found to be beneficial for cotton plant growth, yield and fiber properties. Plant height, No. of sympodial branches/plant, No. of open bolls/plant, seed cotton yield/plant, boll weight, lint $\%$, lint cotton yield/plant, seed index, seed cotton yield/fed, lint cotton yield/fed and fiber properties (upper half mean length, length uniformity index, fiber strength, fiber elongation $\%$, micronaire value and fiber maturity ratio) were found as the most appropriate and beneficial for foliar applications of zinc at $0.4 \%$ and manganese at $0.4 \%$ and iron at 0.4 $\%$.

\section{References}

Abdallah, A. M. and M. F.Y. Hanaa (2013). Effect of foliar application of some micronutrients and growth regulators on some Egyptian cotton cultivars. J. Appl. Sci. Res., 9 (6): 3497-3507.

Ali, A.; M. Tahir; M. Ayub; I. Ali; A. Wasaya and F. Khalid (2009). Studies on the effect of plant spacing on the yield of recently approved varieties of cotton. Pak. J. Life Soc. Sci., 7 (1): 25-30.

Ali, H. and R. A. Hameed (2011). Growth, yield and yield components of American cotton (Gossypium hirsutum, L.) as affected by cultivars and nitrogen fertilizer. Int. J. Sci. \& Eng. Res., 2 (7): 1-13.

Ali, L.; M. Ali and Q. Mohyuddin (2011). Effect of foliar application of zinc and boron on seed cotton yield and economics in cotton-wheat cropping pattern. J. Agric. Res., 49 (2): 173-180.

Alitabar, R. A.; R. Salimbeck; O. Alishah and S. A. Andarkhor (2012). Interactive effects of nitrogen and row spacing on growth and yield of cotton varieties. Int. J. Biol., 4 (3): 124-129.
American stander for testing materials (1986). D: 1578-1967, D: 1425 \& 2256 -1984, D-3818 \& D4605 -1986. USA.

Aslam, M.; A. H. Sanghi; L. Khalid and S. Javed (2013). Effect of different doses of nitrogen on the yield of different cotton varieties. Asian J. Agric. Biol., 1(4): 179-182.

Ayissa, T. and F. Kebede (2011). Effect of nitrogenous fertilizer on the growth and yield of cotton (Gossypium hirsutum, L.) varieties in Middle Awash, Ethiopia. J. Drylands, 4 (1): 248 258.

Baraich, A. A. K.; A. H. K. Baraich; L. A. Jamali and A. U. Salarzi (2012). Effect of nitrogen application rates on growth and yield of cotton varieties. Pak. J. Agric. \& Vet. Sci., 28 (2): 115123.

Egyptian Cotton Gazette (2017). Alcotexa. 149: 51.

El Messiry, M. and S. A. M. Abd-Ellatif (2013). Characterization of Egyptian cotton fibers. Indian J. Fiber \& Textile Res., 38: 109-113.

Elayan, S. E D. (2008). Effect of foliar application of some micronutrients on growth, yield and fiber properties on some Egyptian cotton cultivars. Egypt J. Appl. Sci., 23 (4B): 469 - 485.

Elayan, S. E. D.; A. M. A. Abdalla; N. S. D. AbdelGawad and W. A. E. Faramawy (2015). Effect of delaying planting date on yield, fiber and yarn quality properties in some cultivars and promising crosses of Egyptian cotton. Am-Euras. J. Agric. \& Environ. Sci., 15 (5): 754-763.

Eleyan, S. E. D.; A. A. Abodahab; A. M. Abdallah and R. A. Houda (2014). Effect of foliar application of manganese and iron on growth characters, yield and fiber properties of some Egyptian cotton cultivars (Gossypium barbadense, L.). Intl. J. Agric. Crop Sci., 7 (13): 1283-1292.

El-Kashlan, M. K.; M. S. Saeed and N. A. Abd El.Shafy (1995). Effect of foliar spraying with iron, zinc and manganese on growth and yield of some Egyptian cotton varieties. Egypt, J. App. Sci., 10 (6): 387-398.

El-Sayed, M. A. M. and S. H. Sanad (2007). The impact of new spinning technologies on the Egyptian cottons. AUTEX Res. J., 8 (4): 231-238.

Emara, M. A. A. (2016). Influence of potassium fertilization and spraying of zinc and manganese on cotton growth and productivity. J. Plant Production, Mansoura Univ., 7 (10): 1115 - 1125.

Gomez, K. A. and A. A. Gomez (1984). Statistical Procedures for Agricultural Research. 2 ${ }^{\text {nd }}$, (ed). John Wiley and Sons, NY, U.S.A.

Gururajan, K.N. (2007). Egyptian cotton production to meet the extra-long staple cotton requirement in the country. Model Training Course on (Cultivation of Long Staple Cotton) December 15-22, Central Institute for Cotton Research, Regional Station, Coimbatore, 48-53. 
Ibrahim, I. A. E. (2013). Effect of cotton variety and lint grade on some fiber and yarn properties. J. Appl. Sci. Res., 9 (6): 4015-4020.

Jackson, M. L. (1973). Soil Chemical Analysis, Prentice Hall of India Pvt. Ltd. New Delhi.

Jahedi, M. B.; F. Vazin and M. R. Ramezani (2013). Effect of row spacing on the yield of cotton cultivars. Cercetări Agron. Moldova, 156 (4): $31-38$

Khalid, L.; M. U. Din; M. A. Ali and M. Q. Waqar (2015). Demonstration and evaluation of the effect of foliar application of various nutrients on the growth and yield of cotton in ecological zone of Bahawalnagar Punjab, Pakistan. Int. J. Adv. Res. Biol. Sci., 2 (3): 137-143.

Lindsay, W. L. and W. A. Norvell (1978). Development of DTPA soil test for Zinc, Iron, Manganese and Copper Soil Sci., 42: 241-428.

Mahdy, E. E.; A. Abo-Elwafa; G. H. Abd ElZaher; M. A. Sayed and M.G. Hosein (2017). Tolerance of Egyptian cotton varieties (G. barbadense, L.) to late planting. Assiut J. Agric. Sci., 48 (3): 34-53.

Mamatha, N. (2007). Effect of sulphur and micronutrients (iron and zinc) on yield and quality of cotton in a Vertisol. M. Sc. Thesis, Dep. Soil Sci. Agric Chem., Fac. Agric., Dharwad. Uni. Agric. Sci. India.

Michigan State University (1983). MSTAT-C: Micro-computer Statistical Program, Version 2. Michigan State University, East Lansing.

Nichols, S. P.; C. E. Snipes and M. A. Jones (2004). Cotton growth, lint yield, and fiber quality as affected by row spacing and cultivars. J. Cotton Sci., 8 (1): 1-12.

Radhika, K.; S. Hemalatha; S. P. Katharine; S. Maragatham and A. Kanimozhi (2013). Foliar application of micronutrients in cotton - a review. Res. Rev., J. Agric. Allied Sci., 2 (3): 23-29.

Rezaei, H. and M. J. Malakouti (2001). Critical levels of iron, zinc and boron for cotton in
Varamin rigion. J. Agric. Sci. Technol., 3: 147153.

Saleem, M. F.; M. F. Bilal; M. Awais; M. Q. Shahid and S. A. Anjum (2010). Effect of nitrogen on seed cotton yield and fiber qualities of cotton (Gossypium hirsutum, L.) cultivars. J. Animal \& Plant Sci., 20 (1): 23-27.

Sawan, Z. M.; M. H. Mahmoud and A. H. ElGuibali (2006). Response of yield, yield components, and fiber properties of Egyptian cotton (Gossypium barbadense, L.) to nitrogen fertilization and foliar-applied potassium and mepiquat chloride. J. Cotton Sci., 10 (3): 224-234.

Sawan, Z. M.; M. H. Mahmoud and A. H. ElGuibali (2007). Growth, yield components, yield and fiber properties of Egyptian cotton (Gossypium barbadense, L.) as affected by potassium fertilization and foliar application of zinc and phosphorus. African J. Plant Sci. Biotech., 1 (1): 26-35.

Sawan, Z. M.; M. H. Mahmoud and A. H. ElGuibali (2008). Influence of potassium fertilization and foliar application of zinc and phosphorus on growth, yield components, yield and fiber properties of Egyptian cotton (Gossypium barbadense, L.). J. Plant Ecology, 1(4): 259-270.

Singh,K.; P. Rathore and R. K. Gumber (2015). Effects of foliar application of nutrients on growth and yield of $\mathrm{Bt}$ cotton (Gossypium hirsutum, L.). Bangladesh J. Bot. 44 (1): 9-14.

Soomro, A. W.; A. R. Soomro; A. B. Leghari; M. S. Chang; A. H. Soomro and G. H. Tunio (2000). Effect of boron and zinc micronutrients on seed cotton yield and its components. Pakistan J. Biol. Sci., 3 (12): 2008-2009.

Yaseen, M.; W. Ahmed and M. Shahbaz (2013). Role of foliar feeding of micronutrients in yield maximization of cotton in Punjab. Turk. J. Agric. For., 37: 420-426. 


\section{إستجابة بعض أصناف القطن المصري للرش الخضري ببعض العناصر الصغى

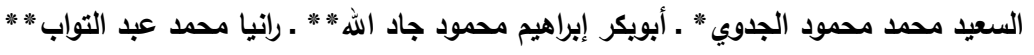

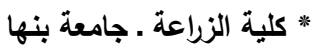

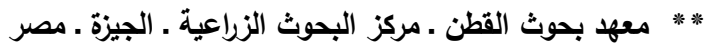

أقيمت تجربتان حقليتان بمزرعة مركز البحوث والتجارب الزراعية بكلية الزراعة بمشتهر جامعة بنها (مركز طوخ ـ محافظة القليوبية .

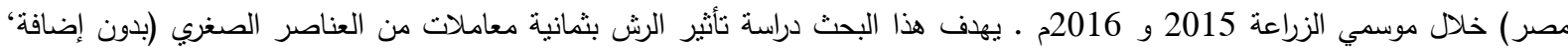
الزنك، المنجنيز" الحديد' الزنك + المنجنيز، الزنك + الحديد' المنجنيز + الحديد و الزنك + المنجنيز + الحديد) على النمو، مكونات المحصول' المحصول وخصائص التيلة في صنفي للقطن المصري (جيزة 86 وجيزة 88). التصميم التجريبي المستخدم هو قطع منشقة مرة واحدة في أربع مكررات. ويمكن تلخيص أهم النتائج فيما يالي:. أثنارت النتائج أن الإختلافات بين صنفي القطن المصري تحت الدراسة كانت معنوية في معظم صفات النمو، مكونات المحصول، المحصول وصفات التيلة المدروسة خلال موسمي الزراعة. صنف القطن جيزة 86 تفوق معنوياً على جيزة 88 في منوسط قيم صفات إرتفاع النبات

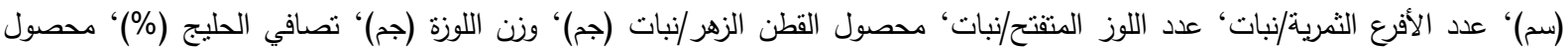
القطن الثعر/نبات (جم)' دليل البذرة (جم)' محصول القطن الزهر/قدان (قنطار)' محصول القطن الثعر /فدان (قنطار)' \% للإستطالة الثعيرات،

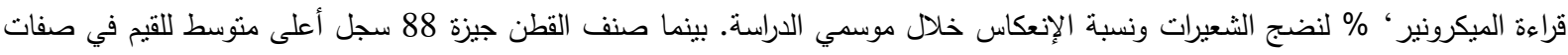
طول أطول الثعيرات(مم)' دليل الإنتظامية في الطول (\%)؛ مثانة الشعيرات (جم/تكس) و ودرجة الإصفرار خلال موسمي الدراسة.

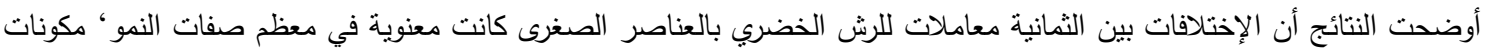

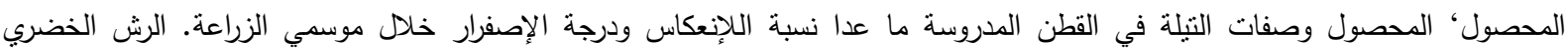

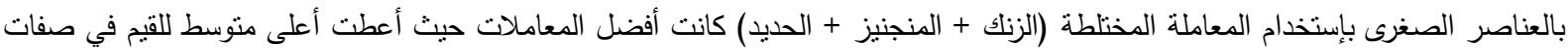

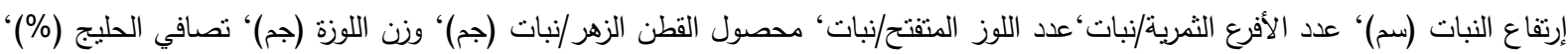
محصول القطن الثعر/نبات (جم)' دليل البذرة (جم)' محصول القطن الزهر/فدان (قنطار)' محصول القطن الثعر/فدان (قنطار)' طول أطول الثعيرات (مم) دليل الإنتظامية في الطول (\%) ' متانة الثعيرات (جم/تكس)، \% للإسنطالة الشعيرات، قراءة المبكرونير و \% لنضج الشعبرات في

أثنارت النتائج إلى أن زراعة القطن المصري صنف جيزة 86 ورش النباتات بخليط من العناصر الصغري (الزنك + المنجنيز + الحديد) أعطى معنوياً أفضل متوسط للقيم في صفات عدد اللوز المتفتح/نبات، محصول القطن الزهر/نبات (جم)' وزن اللوزة (جم)' محصول القطن

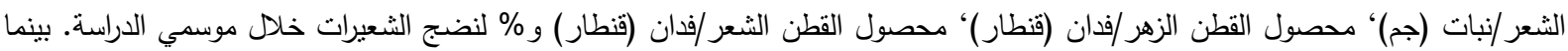
زراعة القطن المصري صنف جيزة 88 ورش النباتات بخليط من العناصر الصغري (الزنك + المنجنيز + الحديد) أنتجت أعلى منوسط للقيم في صفات طول أطول الشعيرات(مم)؛ دليل الإنتظامية في الطول (\%) ومتانة الشعيرات (جم/تكس) خلا موسئ موسي الدراسة. 